\title{
Penerapan Strategi 3M (Meniru, Mengolah, Mengembangkan) untuk Meningkatkan Kemampuan Siswa dalam Menulis Poster
}

\author{
Djoko Santoso ${ }^{(1)}$ \\ ${ }^{1}$ SMP Negeri 3 Kalidawir Tulungagung \\ Email: ${ }^{1}$ djokosantoso@gmail.com, \\ DOI: https://doi.org/10.28926/riset_konseptual.v2i2.45
}

\begin{abstract}
ABSTRAK
Berdasarkan hasil observasi yang dilakukan di Kelas VIII E pada waktu pembelajaran Bahasa Indonesia diperoleh hasil bahwa Ketrampilan menulis siswa kurang memuaskan, Hal ini disebabkan karena guru kurang memberikan penekanan materi yang jelas tentang membuat poster Untuk itu agar dapat meningkatkan Ketrampilan menulis siswa dalam menyelesaikan soal tentang Membuat poster serta untuk tercapainya tujuan pembelajaran perlu diadakan perbaikan pembelajaran dengan menerapkan Pendekatan Metode 3M (Meniru, Mengolah, Mengembangkan). penerapan pembelajaran Membuat poster melalui Pendekatan Metode 3M (Meniru, Mengolah, Mengembangkan) dapat meningkatkan Ketrampilan menulis siswa dalam menyelesaikan soal Membuat poster..
\end{abstract}

Kata kunci: meniru, mengolah, mengembangkan, poster

\section{PENDAHULUAN}

Menulis merupakan salah satu keterampilan berbahasa yang digunakan untuk berkomunikasi. Terdapat empat ketrampilan berbahasa yang mendukung suatu proses komunikasi, ketrampilan tersebut yaitu ketrampilan menyimak, menulis, membaca dan berbicara (Tarigan,2008: 1). Keempat ketrampilan tersebut digunakan untuk berkomunikasi secara langsung maupun tidak langsung.

Menurut Akhidah (1995:2) menulis merupakan aktivitas untuk mengekspresikan ide, gagasan, pikiran atau perasaan ke dalam lambang-lambang kebahasaan. Secara lebih luas, tahapan menulis meliputi tahapan pramenulis, penelitian draf, perbaikan, penyuntingan dan publikasi.

Ketrampilan menulis ini tidak semua orang mampu menulis, apalagi menyukai menulis. Hal ini menunjukkan rendahnya minat menulis pada masyarakat Indonesia. Rendahnya minat kemauan membaca dan menulis pada masyarakat dipengaruhi oleh faktor tingkat kompleksitas ketrampilan menulis dan proses pembelajaran di setiap jenjang pendidikan yang belum optimal (Sutarman, 2009 : 179).

Ketrampilan menulis dianggap ketrampilan yang paling sulit. Hal ini sesuai dengan pendapat Nurgiyantoro (2001 : 396), bahwa dari tiga kemampuan berbahasa lainnya, kemampuan menulis lebih sulit dikuasai bahkan oleh penutur bahasa yang bersangkutan sekalipun. Hal ini disebabkan oleh kemampuan menulis menghendaki pelbagai unsur kebahasaan dan unsur di luar bahasa itu sendiri yang menjadi isi karangan. Baik unsur bahasa maupun unsur isi harus terjalin sedemikian rupa, sehingga menghasilkan karangan yang runtut dan padu. Kesulitan menulis seringkali disebabkan karena kompleksnya permasalahan yang ada dalam pembelajaran menulis.

Poster adalah karya seni atau desain grafis yang memuat komposisi gambar dan huruf pada kertas yang berukuran besar. Pengaplikasiannya dengan ditempel di dinding atau di permukaan datar lainnya dengan sifat mencari perhatian mata pembaca sekuat mungkin. Oleh karena itu, poster dibuat dengan warna-warna yang kontras dan kuat (Yuniarti, 2009 : 1). Kosasih dan Mumpuni (Masipuroh, 20011) mengungkapkan bahwa, poster sebaiknya memiliki pilihan kata dan kalimat yang 
efektif, baik dan benar, bervariasi, persuasive serta tepat sasaran. Selain itu, dalam poster diupayakan adaya gambar yang menarik dan mampu memacu minat serta tergeraknya hati pembaca untuk melakukan apa yang telah dibacanya.

Menulis poster merupakan salah satu pembelajaran menulis di tingkat SMP. Dalam proses pembelajarannya diharapkan dapat menjadi sebuah pembelajaran yang tidak hanya melibatkan kemampuan menuangkan gagasan di selembar kertas, namun poster yang dibuat diharapkan dapat berfungsi untuk mengomunikasikan pesan yang ingin disampaikan. Kegiatan pembelajaran menulis poster ini siswa dipancing untuk memunculkan ide-idenya dan daya pikir kreatifnya melalui bentuk poster yang dibuatnya.

Pada proses pembelajaran Bahasa Indonesia pada kelas VIII-E SMP Negeri 3 Kalidawir Tulungagung, masih ada siswa yang mengalami kesulitan untuk menulis poster sehingga membutuhkan latihan yang terus menerus dan sebagian siswa masih ada yang belum bisa membedakan antara poster dan slogan. Selain itu juga, beliau mengatakan bahwa selama ini guru masih menggunakan strategi konvensional dalam kegiatan pembelajaran sehingga aktivitas pembelajaran yang dilakukan tidak melibatkan secara optimal kemampuan yang dimiliki oleh siswa.

Strategi yang digunakan masih terpaku pada strategi ceramah dan penugasan. Serta dalam proses pembelajaran yang dilakukan tidak banyak melibatkan kemampuan kreativitas siswa. Apabila di setiap kegiatan pembelajaran guru menerapkan strategi ceramah dan penugasan dalam menyampaikan materi, banyak siswa yang tidak tertarik dalam mengikuti kegiatan belajar. Tidak sedikit dari siswa merasa mengantuk dan berbincang dengan teman sebangkunya.

Peneliti juga melakukan wawancara dengan beberapa siswa dari kelas VIII-E SMP Negeri 3 Kalidawir Tulungagung. Mereka merasa kesulitan dalam hal menulis poster, baik kesulitan dalam hal mencari kata-kata, mencari ide dan kurangnya motivasi. Oleh karena itu, dibutuhkan strategi baru yang dapat memberikan suasana pembelajaran yang baru serta memberikan semangat dan motivasi lebih kepada siswa dalam belajar dengan harapan tercapainya hasil belajar yang optimal.

Selain penggunaan strategi belajar yang kurang optimal, penggunaan media belajar pun kurang optimal. Karena media yang terdapat di setiap ruang kelas hanya terdapat papan tulis hitam dan putih. Sedangkan untuk menarik perhatian siswa guru hendaknya menggunakan media pembelajaran yang unik dan menarik sehingga siswa tidak merasa bosan selama kegiatan pembelajran berlangsung. Pernyataan tersebut sesuai dengan pendapat Yuniarti (2010: 2) yang menyatakan bahwa "Proses belajar mengajar pada hakikatnya adalah proses komunikasi, yaitu proses penyampaian pesan dari sumber pesan melalui media tertentu ke penerima pesan yang menciptakan pembelajaran yang menyenangkan."

Peneliti melakukan kegiatan observasi awal pada siswa kelas VIII-E di SMP Negeri 3 Kalidawir Tulungagung, terkait pembelajaran menulis poster. Di sini siswa membuat poster yang berdasarkan pengetahuan dan pengalaman siswa tentang poster. Hal ini bertujuan agar peneliti mengetahui sejauh mana pemahaman siswa terhadap pembelajaran menulis poster.

Pada dasarnya, keterampilan menulis tidak bisa dengan sendirinya. Tarigan (2008: 9) berpendapat, "Keterampilan menulis menuntut latihan yang cukup dan teratur serta pendidikan yang berprogram". Oleh karena itu, latihan menulis secara intensif sangat diperlukan sebab menulis itu merupakan suatu proses. Demikian juga dengan kegiatan menulis poster. Dalam prosesnya kegiatan menulis poster ini membutuhkan latihan yang terus menerus.

Proses pembelajaran menulis poster mengalami kesulitan dalam menuangkan gagasan yang ada dalam benak siswa menjadi sebuah tulisan dan perlunya inovasi sebuah strategi belajar yang baru dalam pembelajaran menulis poster. Inovasi strategi dalam sebuah pembelajaran, terutama pembelajaran Bahasa dan Sastra Indonesia sangatlah diperlukan karena strategi pembelajaran merupakan salah satu komponen pembelajaran yang dapat menentukan ketercapaian tujuan pembelajaran. Oleh karena 
itu, menentukan sebuah strategi dalam sebuah pembelajaran merupakan sesuatu yang penting dalam proses pembelajaran. Anthony (Hidayat dkk, 1990: 1) mengemukakan bahwa "strategi itu sebagai suatu teknik yang digunakan untuk mencapai suatu tujuan".

Dengan demikian guru membutuhkan model, media dan strategi pembelajaran yang mampu menstimulus ide dan daya pikir kreatif siswa dengan suasana belajar yang menyenangkan. Di sini, guru merupakan salah satu komponen yang berperan penting untuk menciptakan suatu keberhasilan dalam proses pembelajaran. Hal ini sesuai dengan pendapat Santyasa (2007: 5) yaitu :

Terdapat beberapa keterampilan dasar mengajar yang harus dipahami dan dapat dipraktikan guru, misalnya kemampuan berpikir siswa, keterampilan reinforcement yaitu keterampilan untuk memberikan penguatan terhadap respon siswa. Keterampilan stimulus yaitu keterampilan untuk mempertahankan konsentrasi siswa dalam mengikuti pelajaran. Di samping itu, guru dituntut memiliki keragaman strategi pembelajaran, karena tidak ada satu strategi pembelajran yang dapat digunakan untuk mencapai tujuan belajar dari topik-topik yang beragam.

Ketentuan-ketentuan yang terdapat dalam kurikulum siswa dituntut untuk memiliki keterampilan kognitif, afektif, dan psikomotor. Menurut peneliti setelah melakukan observasi awal di SMP Negeri 3 Kalidawir Tulungagung menemukan beberapa hal yang menyimpang dalam kegiatan pembelajaran Bahasa Indonesia. Salah satunya, yaitu guru lebih banyak berbicara tentang bahasa dari pada melatih keterampilan penggunaan bahasa secara realistis.

Dengan demikian, untuk mengoptimalkan hasil pembelajaran menulis poster, sebaiknya kita tidak salah dalam memilih sebuah strategi pembelajaran. Oleh sebab itu, dalam penerapan strategi pembelajaran terhadap Standar Kompetensi: Mengungkapkan informasi dalam bentuk rangkuman, poster, slogan/poster dan Kompetensi Dasar: Menulis slogan/poster untuk pelbagai keperluan dengan pilihan kata dan kalimat yang bervariatif, serta persuasif'. Peneliti tidak lagi menggunakan strategi lama yang mengakibatkan proses pembelajaran berlangsung kaku dan monoton. Berdasarkan pertimbangan tersebut, peneliti berusaha untuk memberikan alternatif strategi pembelajaran menulis poster yang kreatif, dan inovatif dengan memanfaatkan fasilitas yang ada.

Strategi copy the master bisa menjadi salah satu strategi alternatif yang selanjutnya dikembangkan menjadi strategi, yaitu strategi 3M (Meniru- MengolahMengembangkan). Strategi pembelajaran 3M (Meniru-Mengolah- Mengembangkan) dipilih sebagai strategi pembelajaran menulis poster karena strategi ini sangat tepat diterapkan dan belum ada peneliti yang menggunakan strategi pembelajaran 3M (Meniru-Mengolah-Mengembangkan) dalam pembelajaran menulis poster.

Menurut Syamsudin (2007: 7) Strategi pembelajaran 3M merupakan singkatan dari meniru, mengolah dan mengembangkan. Pernyataan tersebut diperkuat oleh Nugroho (2009) bahwa "Secara harfiah, copy the master berasal dari bahasa Inggris yang artinya adalah model untuk ditiru. Model yang akan ditiru ini tidak hanya terbatas pada peniruan literal, namun ada tahap perbaikan". Tahapan dalam strategi pembelajaran 3M adalah tahapan meniru, mengolah, lalu mengembangkan. Strategi pembelajaran $3 \mathrm{M}$ ini pun sesungguhnya bukanlah hal yang sangat baru bagi pembelajaran menulis cerpen.

\section{METODE}

Subjek yang digunakan adalah seluruh siswa Kelas VIII E SMP Negeri 3 Kalidawir Tulungagung Tahun Pelajaran 2016/2017 sebanyak 32 siswa yang terdiri dari 19 siswa putra dan 13 siswa putri. Lokasi yang digunakan tempat penelitian adalah ruang Kelas VIII E SMP Negeri 3 Kalidawir Tulungagung Tahun Pelajaran 2016/2017. Pelaksanan Penelitian Perbaikan Pembelajaran dilaksanakan dalam dua siklus yaitu: Siklus Pertama dilaksanakan pada hari Senin, 01 Mei 2017 dan Siklus Kedua dilaksanakan pada hari Senin, 08 Mei 2017,.. Setiap kali pertemuan membutuhkan waktu 80 menit dengan rincian $2 \times 40$ menit. 
Berdasarkan variable yang diteliti dan tujuan yang hendak dicapai, mata metode penelitian yang digunakan adalah dengan teknik korelasi. Dengan berbagai metode yang digunakan peneliti, peneliti berupaya untuk meningkatkan prestasi belajar Bahasa Indonesia terutama pembelajaran Bahasa Indonesia tentang menulis poster Kelas VIII E SMP Negeri 3 Kalidawir Tulungagung dengan menggunakan Metode $3 \mathrm{M}$ (Meniru-mengolah-mengembangkan).

Berdasarkan hasil pengidentifikasian dan penetapan masalah, peneliti kemudian mengajukan suatu solusi yang berupa penerapan Metode $3 \mathrm{M}$ (Menirumengolah-mengembangkan) yang dapat dimanfaatkan Guru untuk digunakan sebagai metode pengajaran dalam pembelajaran Bahasa Indonesia Kelas VIII E SMP Negeri 3 Kalidawir Tulungagung. Penelitian ini dilakukan dengan dua siklus, dimana masingmasing siklus dikenai perlakuan yang sejenis dengan bobot yang beda. Dibuat dua siklus dimaksudkan untuk memperbaiki system pengajaran yang dilaksanakan.

Instrumen yang dikembangkan oleh Guru sebagai peneliti disesuaikan berdasarkan kebutuhan data penelitian itu sendiri. Guru atau peneliti mengidentifikasi dan mempersiapkan berbagai ragam instrument yang diperlukan dalam penelitian tindakan Kelas VIII E ini. Guru ataupun peneliti mempersiapkan instrument penelitian dengan tepat, tentunya supaya data yang terkumpul dapat lebih bermakna dan bermanfaat bagi kegiatan penelitian.

Adapaun ragam instrument penelitian tindakan kelas yang telah dipersiapkan yaitu, Rencana Pelaksaaan Pembelajaran sebagai instrument rencana pelaksanaan tindakan. Lembar observasi Guru sebagai instrument utama pengumpul data proses dan lembar observasi siswa, wawancara, angket dan catatan lapangan sebagai instrument pendukung pengumpul data proses. Selain itu juga terdapat instrument pengumpul data hasil, yang dapat dikumpulkan dari prestasi belajar berdasarkan soalsoal yang diberikan, serta ketrampilan siswa berdasarkan rubrik yang ada.

Teknik analisis yang digunakan yaitu deskriptif persentase. Data hasil penelitian yang dianalisis meliputi rata-rata kelas, ketuntasan belajar individu dan ketuntasan belajar secara klasikal. Selanjutnya hasil analisis data diperoleh baik secara kualitatif (dengan kata-kata) dan kuantitatif (dengan grafik). Hasil ini diinterprestasikan dan disimpulkan untuk menjawab permasalahan yang ada.

Analisis data dari sumber-sumber informasi hasil penelitian di dapat dari: 1) Analisis Data Observasi, Data hasil observasi keterlaksanaan pembelajaran melalui metode 3 M (Meniru-mengolah-mengembangkan)dan observasi aktivitas siswa dianalisis secara deskriptif untuk memberikan gambaran pelaksanaan pembelajaran dengan menggunakan metode $3 \mathrm{M}$ (meniru, mengolah, mengembangkan). 2) Analisis Data Wawancara, Hasil wawancara dengan siswa dianalisi secara deskriptif dengan lembar angket untuk mengetahui pendapat Guru dan siswa terhadap pembelajaran. 3) Analisis Data Tes, Berdasarkan hasil tes siswa, setiap soal diberi skor kemudian diperoleh nilai untuk setiap siswa.

\section{HASIL \\ Pra Siklus}

Dari pengumpulan data, nilai ulangan harian tentang Bahasa Indonesia tentang menulis poster, rata-rata nilai yang didapat hanya sebesar 63,1. Dari 32 siswa, hanya 9 siswa yang mendapat nilai di atas 70 . Ini berarti hanya $28,1 \%$ siswa yang telah mencapai ketuntasan belajar, karena Kriteria Ketuntasan Minimal (KKM) telah ditentukan sebesar 70 .

Tabel berikut adalah daftar frekuensi nilai ulangan harian Bahasa Indonesia tentang menulis poster siswa Kelas VIII-E SMP Negeri 3 Kalidawir Tulungagung, dengan nilai KKM sebesar 70: 
Tabel 1 Daftar Nilai Ulangan Harian Kondisi Awal

\begin{tabular}{|l|l|l|}
\hline Nilai & Frekuensi & Prosentase \\
\hline $0-40$ & 3 & $9.4 \%$ \\
\hline $41-69$ & 20 & $62.5 \%$ \\
\hline $70-100$ & 9 & $28.1 \%$ \\
\hline Jumlah & 32 & $100 \%$ \\
\hline
\end{tabular}

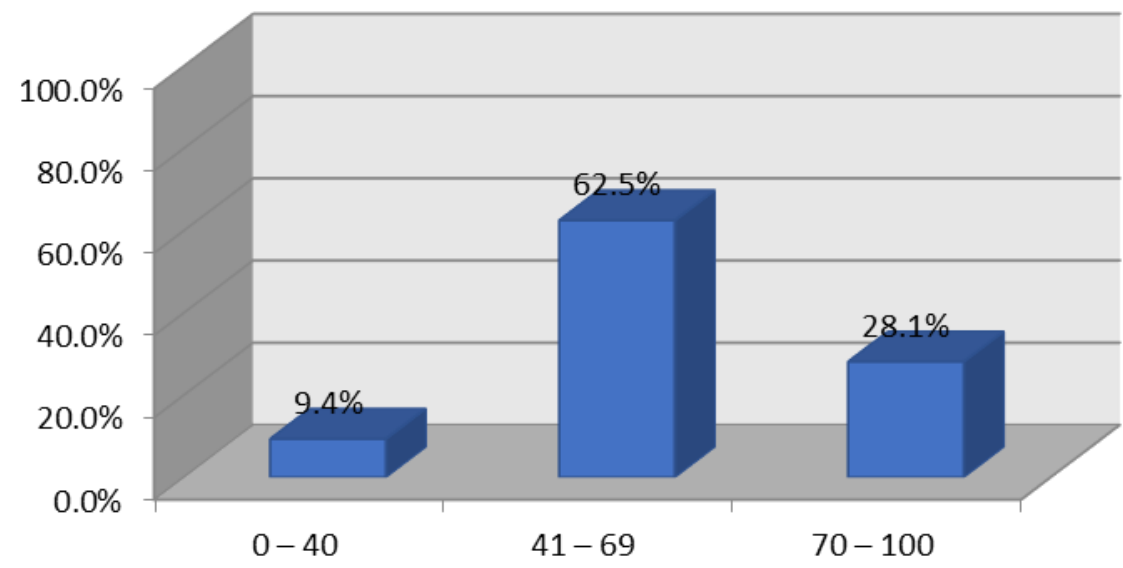

\section{Gambar 1 Grafik Frekuensi Nilai}

Dari tabel diatas dapat kita lihat bahwa terdapat 3 siswa atau 9,4\% yang mendapat nilai antara $0-40$, ada 20 siswa atau $62.5 \%$ yang mendapat nilai antara 41 - 69, dan ada 9 siswa atau 28.1\% yang mendapat nilai antara 70 - 100. Dengan ketentuan nilai KKM 70, maka dapat disimpulkan jika pencapaian prestasi nilai 70 100 yang hanya $28.1 \%$ merupakan prestasi yang rendah.

Selain itu, dari proses wawancara diperoleh kesimpulan bahwa siswa kurang berminat dalam mengerjakan soal tentang menulis poster, serta dalam pembelajaran Guru lebih sering menggunakan ceramah sehingga siswa merasa jenuh dan bosan, akibatnya minat siswa untuk belajar Bahasa Indonesia terutama pada tentang menulis poster menjadi berkurang sehingga mempengaruhi hasil prestasinya.

Berdasarkan hasil data yang dikumpulkan, dapat dikemukakan dua hal pokok yang perlu diatasi, yaitu menumbuhkan minat siswa untuk belajar Bahasa Indonesia dan memahamkan tentang menulis poster dengan cara mengaktifkan siswa dalam kegiatan belajar mengajar dan meningkatkan prestasi belajar siswa dengan menerapkan $3 \mathrm{M}$ (meniru-mengolah-mengembangkan) pada siklus 1 nanti dengan harapan prestasi belajar siswa dapat meningkat.

Jika pada siklus 1, target indikator pencapaian prestasi belajar masih kurang dari 85\% maka akan dilanjutkan dengan siklus 2 dan seterusnya, hingga target indicator pencapaian peningkatan prestasi belajar siswa pada pelajaran Bahasa Indonesia khususnya pembelajaran Bahasa Indonesia tentang menulis poster dapat terpenuhi, yaitu $85 \%$ atau lebih.

\section{Siklus I}

Dalam pelaksanaan pembelajaran, Guru masih menghadapi berbagai kendala, antara lain: Masih ada kelompok yang bingung dalam mengikuti langkahlangkah yang tertera dalam lembar kegiatan. Masih ada beberapa siswa yang belum aktif dalam pelaksanaan percobaan. Ketika pelaksanaan diskusi, ada beberapa siswa yang tidak aktif menyampaikan pendapatnya. Dalam menyimpulkan hasil percobaan, terdapat 2 (dua) kelompok yang malu untuk presentasi, dan hanya terdapat 4 (empat) siswa yang mengajukan pertanyaan. 
Vol. 2 No. 2, April 2018;

Adapun prosentase hasil observasi dalam pelaksanaan percobaan pada siklus I dapat dilihat dari tabel 3 bawah ini. Perhitungan prosentase keberhasilan siklus I di bawah ini diskusikan juga dengan teman sejawat.

\section{Tabel 2 Prosentase Hasil Observasi Siklus I}

\begin{tabular}{|l|l|l|}
\hline No & Kegiatan Siswa & Prosentase \\
\hline 1 & Pembagian Kelompok & $50 \%$ \\
\hline 2 & Keruntutan langkah & $65 \%$ \\
\hline 3 & Aktif melaksanakan kegiatan & $57 \%$ \\
\hline 4 & Aktif mengutarakan pendapat & $63 \%$ \\
\hline 5 & Kesimpulan akhir & $59 \%$ \\
\hline
\end{tabular}

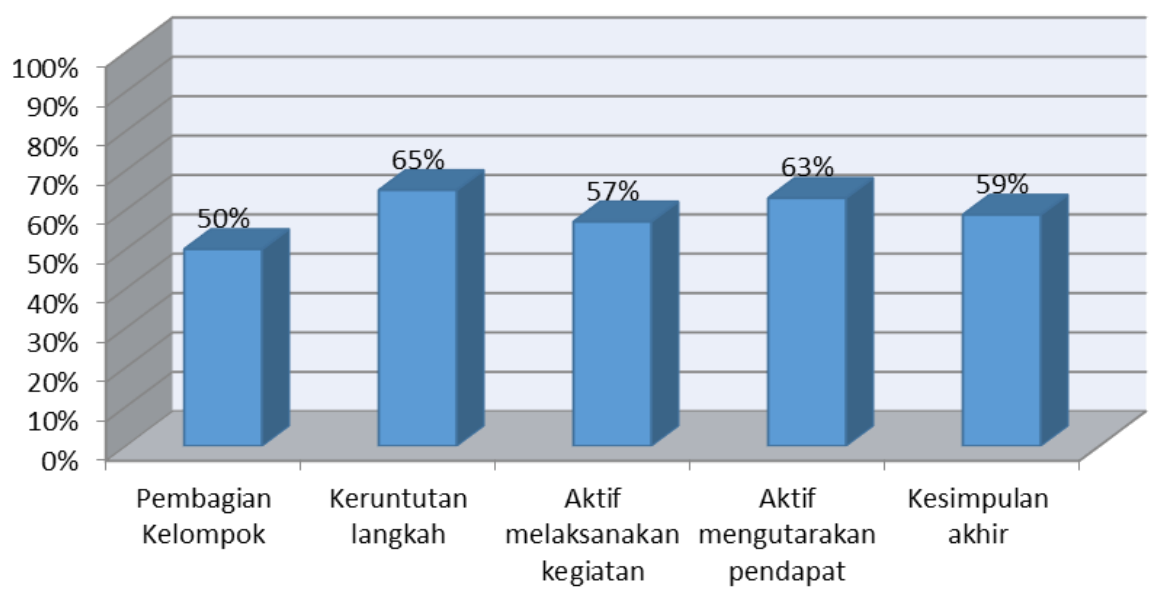

\section{Gambar 2 Grafik Histogram Prosentase Hasil Observasi Siklus I}

Hasil post test pada siklus pertama dapat menjadi perhitungan persentase peningkatan prestasi belajar siswa. Dengan acuan penilaian tetap berdasarkan nilai KKM yang telah ditetapkan yaitu paling sedikit siswa memperoleh nilai 70 . Adapun rekapitulasi hasil test siklus I adalah sebagai berikut:

Tabel 3 Hasil Post Test Siklus Pertama

\begin{tabular}{|l|l|l|}
\hline No & Deskripsi & Nilai \\
\hline 1 & Jumlah Nilai & 2341 \\
\hline 2 & Rata-rata Hasil Post Test & 73.2 \\
\hline 3 & Jumlah siswa yang mendapat nilai diatas KKM (70) & 21 \\
\hline 4 & Presentase siswa yang mendapat nilai diatas KKM (70) & $65.6 \%$ \\
\hline 5 & Jumlah siswa yang mendapat nilai dibawah KKM (70 & 11 \\
\hline 6 & Presentase siswa yang mendapat nilai dibawah KKM (70) & $34.4 \%$ \\
\hline
\end{tabular}

Nilai rata-rata hasil post test, dapat dihitung dari : $\dot{X}=\frac{\sum X}{\sum N}$, Jadi $\dot{X}=$ $\frac{2341}{32}=73.2$. Nilai $\mathrm{KKM}=70$. Jadi sudah ada peningkatan prestasi belajar, namun hanya sedikit. Rumus Ketuntasan Individu (prestasi belajar siswa) = Esiswa yang mendapat nilai $\geq 70$

Esiswa $\quad$ x 100\%. Jadi, Ketuntasan Individu (prestasi belajar siswa) $=\frac{21}{32} \times 100 \%=65.6 \%$. Masih kurang dari indicator pencapaian siklus I sebesar $85 \%$ 
atau lebih. Maka dilanjutkan percobaan pembelajaran dengan $3 \mathrm{M}$ (meniru-mengolahmengembangkan) pada siklus II.

Tabel berikut adalah daftar frekuensi nilai post test siklus I Bahasa Indonesia tentang menulis poster siswa Kelas VIII-E SMP Negeri 3 Kalidawir Tulungagung setelah pembelajaran menggunakan $3 M$ (meniru-mengolah-mengembangkan), dengan nilai minimal KKM sebesar 70

Tabel 4 Daftar Nilai Ulangan Harian Siklus I

\begin{tabular}{|l|l|l|}
\hline Nilai & Frekuensi & Prosentase \\
\hline $0-40$ & 0 & $0.0 \%$ \\
\hline $41-69$ & 11 & $34.4 \%$ \\
\hline $70-100$ & 21 & $65.6 \%$ \\
\hline Jumlah & 32 & $100 \%$ \\
\hline
\end{tabular}

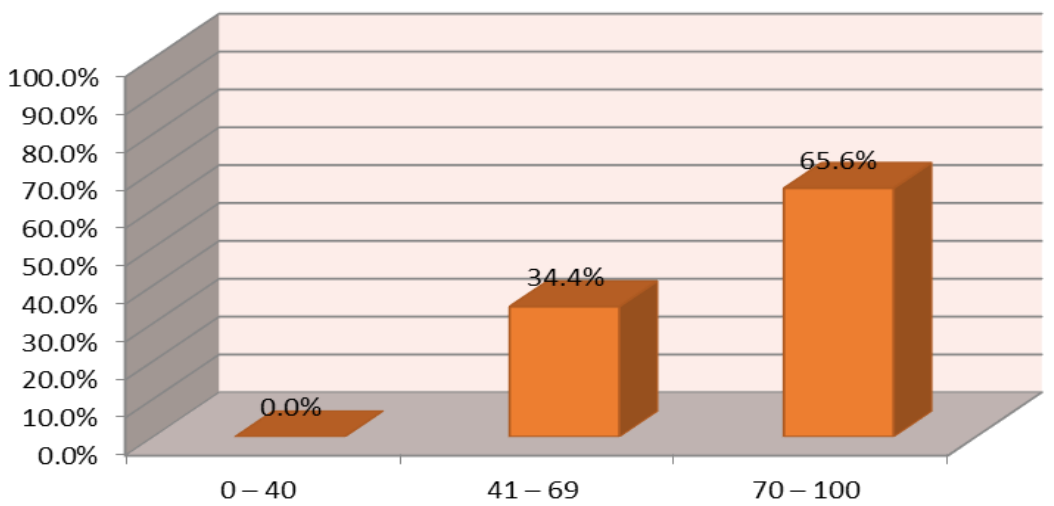

\section{Gambar 3 Grafik Frekuensi Nilai Siklus I}

Dari tabel diatas dapat kita lihat terdapat 11 siswa atau 34,4\% yang mendapat nilai antara $41-69$, dan 21 siswa atau 62,5\% yang mendapat nilai antara $70-100$. Dengan ketentuan nilai KKM 70, dapat disimpulkan jika pencapaian prestasi nilai 70 100 , maka prestasi belajar siswa telah meningkat dari $28,1 \%$ menjadi $65,6 \%$. Namun karena belum mencapai target indikator pencapaian siklus I sebesar $85 \%$ atau lebih, maka akan dilanjutkan ke Siklus II.

Selain itu, dari proses wawancara diperoleh kesimpulan bahwa beberapa siswa menjadi bersemangat dalam belajar Bahasa Indonesia, karena pelaksanaan kegiatan belajar Bahasa Indonesia dengan $3 \mathrm{M}$ (meniru-mengolah-mengembangkan) ini dilaksanakan dengan langsung secara mandiri oleh siswa, dan melaksanakan kegiatan bersama kelompok sehingga lebih ringan.

\section{Siklus II}

Guru telah melaksanakan perbaikan dari siklus I, siswa sudah mengalami kemajuan dan pelaksanaan-pun telah berjalan baik. Namun Guru menemukan masalah baru dalam pelaksanaan siklus II, yaitu: Beberapa siswa ramai dalam mengerjakan lembar kerja siswa. Masih terdapat 2 siswa yang malu dalam presentasi dan kurang aktif dalam diskusi kelompok.

Adapun prosentase hasil observasi dalam pelaksanaan percobaan pada siklus II dapat dilihat dari tabel bawah ini. Perhitungan prosentase keberhasilan siklus II di bawah ini diskusikan juga dengan teman sejawat. 


\section{Tabel 5 Prosentase Hasil Observasi Siklus II}

\begin{tabular}{|l|l|l|}
\hline No & Kegiatan Siswa & Prosentase \\
\hline 1 & Pembagian Kelompok & $85 \%$ \\
\hline 2 & Keruntutan langkah & $92 \%$ \\
\hline 3 & Aktif melaksanakan kegiatan & $90 \%$ \\
\hline 4 & Aktif mengutarakan pendapat & $88 \%$ \\
\hline 5 & Kesimpulan akhir & $89 \%$ \\
\hline
\end{tabular}

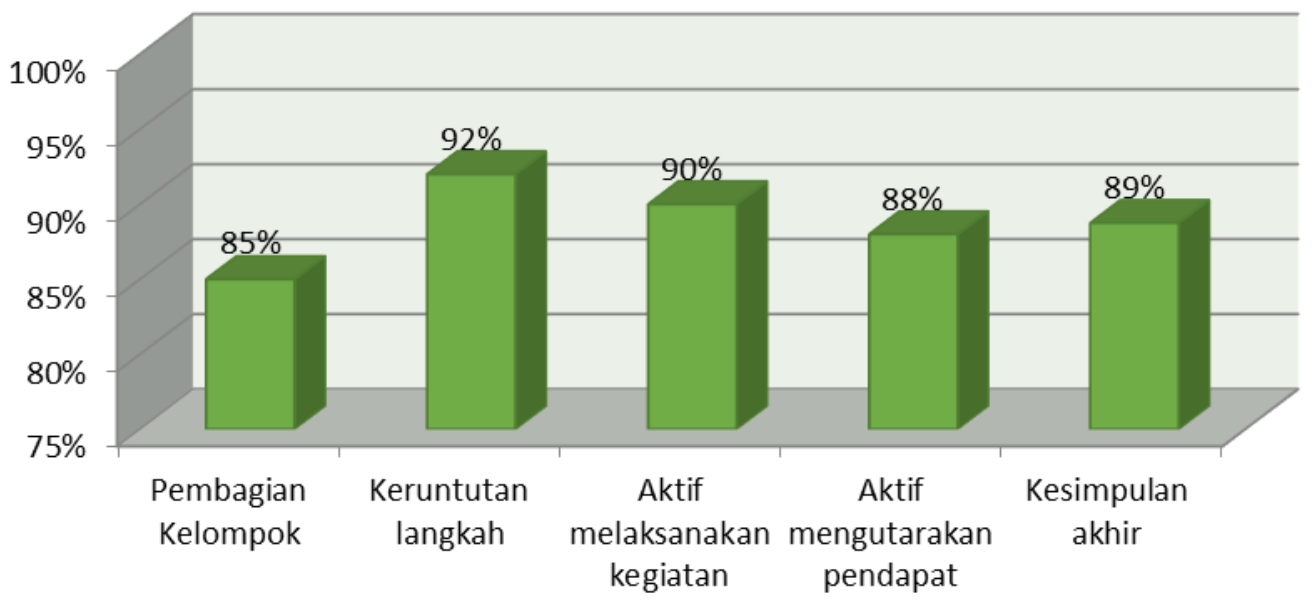

Gambar 4 Grafik Histogram Prosentase Hasil Observasi Siklus II

Hasil post test pada siklus kedua dapat menjadi perhitungan persentase peningkatan prestasi belajar siswa. Dengan acuan penilaian tetap berdasarkan nilai KKM yang telah ditetapkan yaitu paling sedikit siswa memperoleh nilai 70 . Adapun rekapitulasi hasil test siklus II adalah sebagai berikut.

\section{Tabel 6 Hasil Post Test Siklus Kedua}

\begin{tabular}{|l|l|l|}
\hline No & Deskripsi & Nilai \\
\hline 1 & Jumlah Nilai & 2656 \\
\hline 2 & Rata-rata Hasil Post Test & 82,9 \\
\hline 3 & Jumlah siswa yang mendapat nilai diatas KKM (70) & 29 \\
\hline 4 & $\begin{array}{l}\text { Presentase siswa yang mendapat nilai diatas KKM } \\
(70)\end{array}$ & $90,6 \%$ \\
\hline 5 & Jumlah siswa yang mendapat nilai dibawah KKM (70 & 3 \\
\hline 6 & $\begin{array}{l}\text { Presentase siswa yang mendapat nilai dibawah KKM } \\
(70)\end{array}$ & $9,4 \%$ \\
\hline
\end{tabular}

Nilai rata-rata hasil post test, dapat dihitung dari : $\dot{X}=\frac{\sum X}{\sum N}$, Jadi $\dot{X}=$ $\frac{2656}{32}=82,9$. Nilai $\mathrm{KKM}=70$. Jadi sudah ada peningkatan prestasi belajar yang signifikan. Rumus Ketuntasan Individu (prestasi belajar siswa) = Esiswa yang mendapat nilai $\geq 70$

Esiswa $\quad \times 100 \%$. Jadi, Ketuntasan Individu (prestasi belajar siswa) $=\frac{29}{32} \times 100 \%=90,6 \%$. Telah mencapai indicator pencapaian siklus II sebesar $85 \%$ atau lebih. Maka tidak perlu dilanjutkan percobaan pembelajaran dengan $3 \mathrm{M}$ (menirumengolah-mengembangkan) pada siklus III.

Tabel berikut adalah daftar frekuensi nilai post test siklus II Bahasa Indonesia tentang menulis poster siswa Kelas VIII E SMP Negeri 3 Kalidawir Kabupaten 
Vol. 2 No. 2, April 2018;

Tulungagung setelah pembelajaran menggunakan $3 \mathrm{M}$ (meniru-mengolahmengembangkan) siklus II, dengan nilai minimal KKM sebesar 70 .

Tabel 7 Daftar Nilai Ulangan Harian Siklus II

\begin{tabular}{|l|l|l|}
\hline Nilai & Frekuensi & Prosentase \\
\hline $0-40$ & 0 & $0.0 \%$ \\
\hline $41-69$ & 3 & $9.4 \%$ \\
\hline $70-100$ & 29 & $90.6 \%$ \\
\hline Jumlah & 32 & $100 \%$ \\
\hline
\end{tabular}

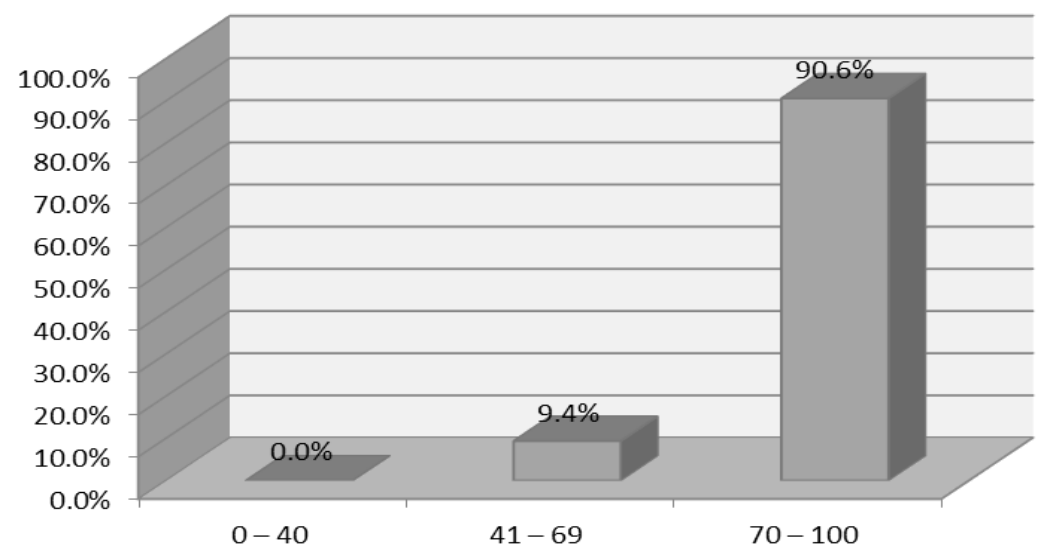

Gambar 5 Grafik Frekuensi Nilai Siklus II

Dari tabel diatas dapat kita lihat terdapat 3 siswa atau 9,4\% yang mendapat nilai antara 41 - 69, dan 29 siswa atau 90,6\% yang mendapat nilai antara $70-100$. Dengan ketentuan nilai KKM 70, dapat disimpulkan jika pencapaian prestasi nilai 70 100 , maka prestasi belajar siswa telah meningkat dari $65,6 \%$ menjadi $90,6 \%$. Dengan $90,6 \%$ maka telah tercapai indicator pencapaian siklus II sebesar yang $85 \%$ atau lebih, maka tidak perlu dilanjutkan ke Siklus III.

Selain itu, dari proses wawancara diperoleh kesimpulan bahwa beberapa siswa menjadi bersemangat dalam belajar Bahasa Indonesia, karena pelaksanaan kegiatan belajar Bahasa Indonesia yang ber $3 \mathrm{M}$ (meniru-mengolah-mengembangkan) ini dilaksanakan dengan mandiri, menyenangkan dan kompak, serta melaksanakan kegiatan bersama kelompok menjadikan mereka lebih rileks dan ringan dalam mengerjakan laporan kegiatan.

\section{PEMBAHASAN}

Berdasarkan hasil pelaksanaan pada siklus I, II dapat dinyatakan bahwa terjadi peningkatan kualitas pembelajaran yang tampak dan perolehan hasil evaluasi dan keaktifan siswa. Dari tabel 4.2 dan gambar 4.2 siklus I hasil observasi menunjukkan, prosentase keberhasilan kelengkapan menyiapkan alat dan bahan percobaan 50\%, prosentase keruntutan langkah-langkah yang ditempuh dalam pelaksanaan percobaan $65 \%$, prosentase keaktifan siswa dalam melaksanakan kegiatan percobaan $57 \%$, prosentase keaktifan siswa dalam mengutarakan pendapat saat berdiskusi $63 \%$ dan prosentase hasil penarikan kesimpulan akhir sesuai percobaan $59 \%$.

Berdasarkan tabel 4.5 dan gambar 4.4 siklus II hasil observasi menunjukkan, prosentase keberhasilan metode kelengkapan menyiapkan alat dan bahan percobaan siswa yang disiapkan $85 \%$, prosentase keruntutan langkah-langkah yang ditempuh dalam pelaksanaan percobaan $92 \%$, prosentase keaktifan siswa dalam melaksanakan kegiatan percobaan $90 \%$, prosentase keaktifan siswa dalam mengutarakan pendapat 
saat berdiskusi $88 \%$ dan prosentase hasil penarikan kesimpulan akhir sesuai percobaan $89 \%$.

Dari daftar nilai (lihat lampiran) dapat kita lihat adanya prosentase kenaikan nilai Bahasa Indonesia mulai dari kondisi awal pra tindakan, diketahui baru 9 siswa atau $28,1 \%$ yang mengalami ketuntasan belajar dan mendapatkan nilai sesuai dengan KKM. Hasil evaluasi siklus I menunjukkan baru 21 siswa atau $34,4 \%$ yang mengalami ketuntasan belajar dan mendapat nilai sama dengan atau di atas KKM yaitu 70. Hal itu menunjukkan bahwa pelaksanaan siklus I belum mencapai keberhasilan, karena indicator pencapaian adalah sebesar $85 \%$ atau lebih. Siklus II menunjukkan ada 29 siswa atau 90,6\% dari 32 siswa yang mengalami ketuntasan belajar. Sehingga peneliti menyimpulkan bahwa pada siklus II ini peneliti telah mencapai keberhasilan dari penelitian tindakan kelas yang telah dilakukan.

Ketika peneliti melaksanakan siklus I, peneliti mengalami berbagai kendala antara lain masih ada siswa yang kesulitan dalam mengembangkan poster dengan kalimat yang persuatif. Masih ada kelompok yang bingung dalam mengikuti langkahlangkah yang tertera dalam lembar kegiatan. Masih ada beberapa siswa yang belum aktif dalam pelaksanaan percobaan. Ketika pelaksanaan diskusi, ada beberapa siswa yang tidak aktif menyampaikan pendapatnya. Dalam menyimpulkan hasil percobaan, terdapat 6 (tiga) kelompok yang malu untuk presentasi, dan hanya terdapat 3 (empat) siswa yang mengajukan pertanyaan.

Peneliti kemudian melaksanakan siklus II sebagai perbaikan siklus I, sebelum pelaksanaan siklus II ini peneliti mengganti rencana pembelajaran $3 \mathrm{M}$ (menirumengolah-mengembangkan) baru yaitu dengan menulis poster dengan tema yang telah ditentukan. Dalam pelaksanaan percobaan, peneliti senantiasa memberi bimbingan untuk siswanya dalam melaksanakan langkah-langkah sesuai lembar kegiatan. Peneliti pun memberi bimbingan siswa saat berdiskusi untuk menarik kesimpulan. Dengan adanya motivasi guru berupa reward, siswa telah terlihat aktif dalam kegiatan pembelajaran dalam melaksanakan percobaan, presentasi di depan kelas dan berdiskusi menarik kesimpulan. Meskipun ada kendala yaitu siswa kesulitan dalam menentukan kalimata poster yang persuatif sehingga suasana menjadi gaduh, namun dengan hasil prestasi belajar yang dicapai dapat disimpulkan bahwa penelitian tindakan kelas dari siklus II ini telah berhasil.

\section{KESIMPULAN}

Berdasarkan hasil penelitian tindakan kelas yang telah dilaksanakan dalam 2 siklus dengan menerapkan metode $3 \mathrm{M}$ (meniru-mengolah-mengembangkan) dalam pembelajaran Bahasa Indonesia pada siswa Kelas VIII-E SMP Negeri 3 Kalidawir Tulungagung, dapat dibuat kesimpulan sebagai berikut: Penerapan metode $3 \mathrm{M}$ (meniru-mengolah-mengembangkan) dapat meningkatkan prestasi belajar Bahasa Indonesia siswa Kelas VIII-E SMP Negeri 3 Kalidawir Tulungagung.

\section{SARAN}

Berdasarkan hasil penelitian, maka ada beberapa saran yang dapat dipergunakan sebagai bahan pertimbangan dan sebagai bahan uraian penutup penelitian tindakan kelas ini, antara lain: 1) Bagi Guru, Hendaknya mempersiapkan secara cermat perangkat pendukung pembelajaran dan fasilitas belajar yang diperlukan, karena sangat mempengaruhi efektivitas dan efisiensi pembelajaran yang pada akhirnya berpengaruh pada proses dan prestasi belajar Bahasa Indonesia siswa. Guru juga harus memahami dan memvariasikan metode yang sesuai materi yang dapat digunakan dalam proses pembelajaran, sehingga siswa tidak merasa bosan. 2) Bagi Siswa Hendaknya ikut berperan aktif dalam proses pembelajaran, selalu mengerjakan tugas-tugas yang diberikan guru dan meningkatkan usaha belajar sehingga dapat memperoleh prestasi yang diharapkan. 3) Bagi Sekolah, Hendaknya mengupayakan pengadaan berbagai media pembelajaran Bahasa Indonesia, baik bantuan maupun swadaya sekolah, sehingga lebih menunjang dalam penanaman 
konsep-konsep Bahasa Indonesia secara lebih nyata sekaligus meningkatkan aktivitas belajar siswa.

\section{DAFTAR RUJUKAN}

Ahmadi, H. 1990. Strategi Belajar MengajarKeterampilan Berbahasa Apresiasi Sastra. Malang: YA3 Malang.

Akhadiah, S., dkk. 1995. Pembinaan Kemampuan Menulis Bahasa Indonesia. Jakarta: Erlangga.

Depdikbud. 2006. Kurikulum Tingkat Satuan Pendidikan (KTSP-SMP). Jakarta: Departemen Pendidikan Nasional.

Depdiknas, 2008. Pedoman Penyusunan KTSP SMP. Jakarta: BSNP.

Makmun, AS. 2007. Psikologi Pendidikan. Bandung: PT Rosda Karya Remaja.

Mulyasa, E. 2009. Implementasi Kurikulum Tingkat Satuan Pendidikan. Jakarta: Bumi Aksara.

Nugroho. 2009. Membuat Siswa Aktif. Bandung: Bandar Maju.

Nurgiyantoro, A. 2001. Penilaian dalam Pengajaran Bahasa dan Sastra. Yogyakarta: BPFE.

Santyasa. 2007. Keterampilan Dasar Menulis. Jakarta: Universitas Terbuka.

Sudjana, N., \& Ibrahim. 1989. Penelitian dan Penilaian Pendidikan. Bandung: Sinar Baru.

Sutarman, A. 2009. Evaluasi Pembelajaran. Bandung: Remaja Rosdakarya.

Tarigan, H.G. 2008. Menulis Sebagai Suatu Keterampilan Berbahasa. Bandung: Angkasa

Usman. 1993. Proses Belajar Mengajar. Bandung: PT Rosdakarya

Yuniarti, H. 2009. Strategi Pembelajran Aktif. Yogyakarta: Pustaka Insani Madani. 